\title{
Mechanism of Action of Antimicrobial Peptides Against Bacterial Membrane
}

\author{
Jong-Kook Lee ${ }^{1}$ and Yoonkyung Park ${ }^{1,2, *}$ \\ ${ }^{I}$ Research Center for Proteinaceous Materials (RCPM), Chosun University, Gwangju; ${ }^{2}$ Department of \\ Biotechnology, Chosun University, Gwangju, Korea
}

\begin{abstract}
Resistance to antibiotics is becoming a very serious problem, with so-called superbugs exhibiting resistance to nearly all conventional antibiotic drugs. Consequently, these organisms often cause severe illness and even death. Alternatives to conventional antibiotics are antimicrobial peptides (AMPs). These widely expressed short peptides, which have been isolated from insects, plants, marine organisms and mammals, including humans, show strong antimicrobial activity against both Gram-negative and Gram-positive bacteria. Most AMPs act by disrupting the bacterial membrane through "Barrel-stave", "Toroidal pore", "carpet" mechanism. In addition, AMPs may prevent septic shock through strongly binding lipopolysaccharides and lipoteichoic acid located on the bacterial membrane. The action mechanisms of AMP to minimize the likelihood developing resistance to the peptides would be particular advantage. For these reasons, we anticipate that AMPs will replace conventional antibiotic drugs in a variety of contexts.
\end{abstract}

Key Words: Superbug, Antimicrobial peptide, Lipopolysaccharides, Lipoteichoic acid, AMP mechanism

\section{INTRODUCTION}

현대를 살아가는 많은 사람들은 변화된 식생활과 환경 오염 그리고 스트레스 증가 등에 의해 신체의 자가면역 력이 저하되고 있으며, 각종 미생물에 의한 감염 증가는 여러 질병 발생으로 이어져 심각한 문제가 되고 있다. 이 런 미생물감염에 대한 질병 예방 및 치료 목적으로 많 은 약물이 이용되고 있지만, 각종 약물의 오·남용은 심 각한 질병을 유발하는 저항성 병원균을 유도했다. 특히, "Superbugs"로 알려진 methicillin-resistant Staphylococcus aureus와 multidrug resistant pathogens 등의 급격한 증가는 세계적으로 많은 관심의 대상이 되고 있다 (1 3). 대부분
의 항생제는 $\beta$-락탐 계열로 미생물 막을 투과하여 성장 억제작용을 주요 목표로 세포막 합성(cell wall synthesis), 테트라하이드로엽산 생합성(tetrahydrofolate biosynthesis), 복제기구(replication machinery), 전사기구(transcription machinery) 그리고 단백질 합성(protein synthesis)에 영향을 미친다. "Superbugs"와 같은 저항성 균의 출현은 미생물 막 의 배출펌프(efflux pump), 유전자변형(genetic modification), 미생물이 생산한 효소 등에 의해 형태변형 또는 약물을 파괴함으로써 약물에 저항성을 갖는다 (4). 또한, 약물에 심각한 저항성을 갖는 것들 중 하나로 미생물의 생육조 건이 부적절할 때 미생물 내부로부터 외부로 분비되는 물질(extracellular polymeric substance: EPS)에 의해 형성되 는 생물막(biofilm)이 있다. 이러한 생물막 형성 시 분비

Received: April 30, 2014/ Revised: May 8, 2014/ Accepted: May 10, 2014

* Corresponding author: Yoonkyung Park. Department of Biotechnology, Chosun University, Gwangju 501-759, Korea.

Phone: +82-62-230-6854, Fax:+82-62-225-6758, e-mail: y_k_park@chosun.ac.kr

** This work was supported by the IPET (Korea Institute of Planning and Evaluation for Technology in Food, Agriculture, Forestry and Fisheries), Ministry for Food, Agriculture, Forestry and Fisheries, Republic of Korea, the National Research Foundation of Korea (NRF) grant funded by the Korea government (MEST) (No. 2011-0017532) and the Human Resource Training Project for Regional Innovation (NRF-2013H1B8A2032054).

(c) This is an Open Access article distributed under the terms of the Creative Commons Attribution Non-Commercial License (http://creativecommons.org/license/by-nc/3.0/). 
되는 물질은 전체적으로 알려지지 않았지만 다량 함유 된 물질로는 단백질, 다당류(polysaccharide), 그리고 핵산 (nucleic acids) 등이 존재하며, 이들 물질들에 의해 각종 약물들이 저항성을 갖는 것으로 보고되었다 (5 7). 이러 한 "Superbugs"의 출현은 항생제 내성의 증가로 응급상황 에서 생명에 위협을 나타내기도 한다.

각종 약물에 저항성을 갖는 "Superbugs"의 출현으로 신규 항생물질을 발견하거나 고안하는 것이 시급한 문
제로 대두되며, 다양한 항생 물질 중 하나인 펩타이드 (peptide)는 살아있는 유기체인 곤충, 식물, 동물, 해양생 물 그리고 인간 등에게서 분리되는 것으로 보고되었다. 각종 유기체에서 분비된 펩타이드는 호르몬조절, 신호전 달, 항암효과 그리고 항균/항진균 효과 등의 생리활성작 용에 중요한 역할을 하는 물질로 알려져 있다 $(8,9)$. 항균 활성 펩타이드는 약 50 개의 아미노산에 의해 펩타이드 본드를 형성하여 이루어 진 것으로, Lysine과 Arginine에

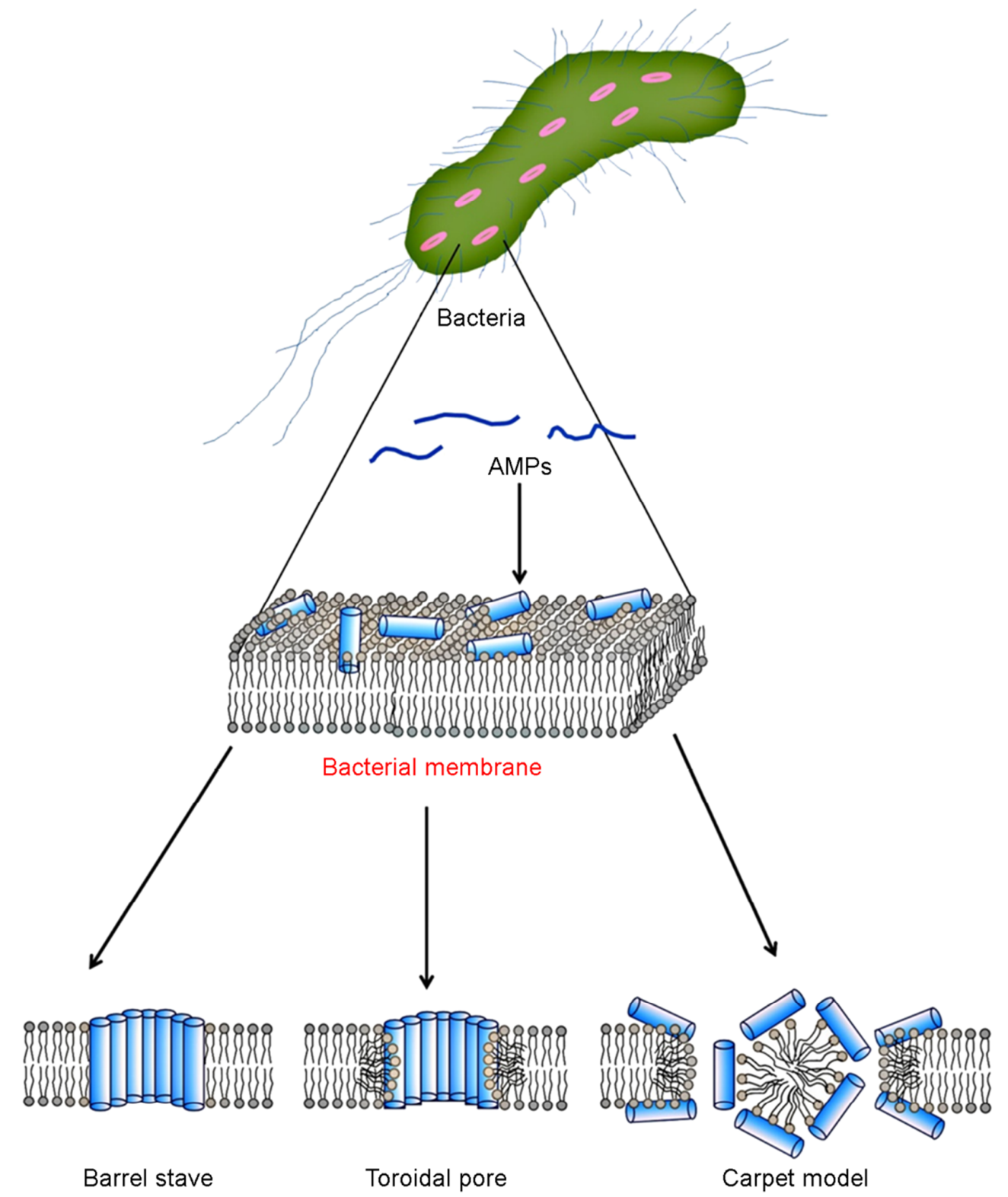

Figure 1. Action mechanism of antimicrobial peptides (AMPs) on the bacterial membrane. 


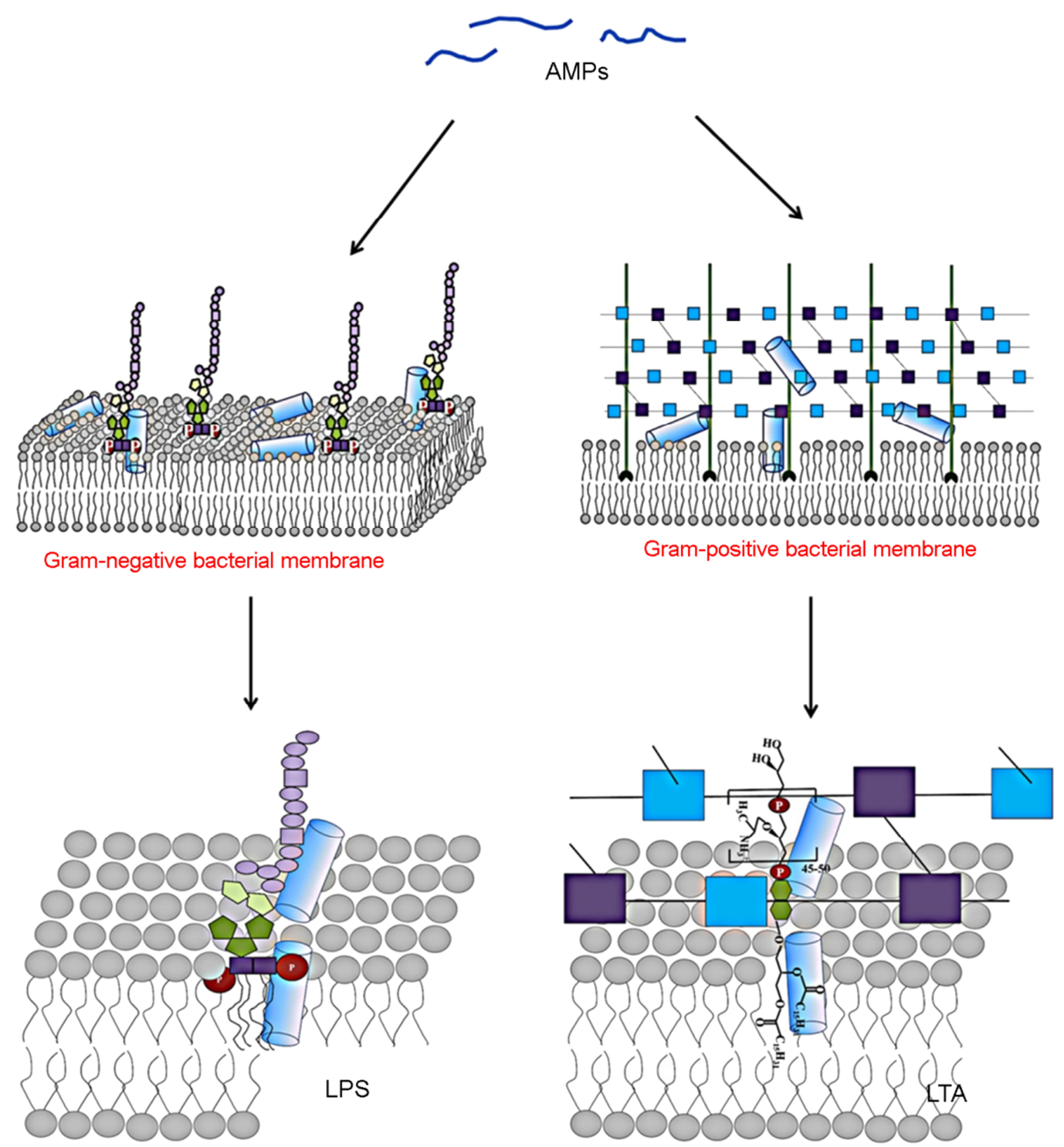

Figure 2. Binding affinity of antimicrobial peptide on the lipopolysaccharides (LPS) and lipoteichoic acid (LTA) in membranes of Gram-negative and Gram-positive bacteria.

의해 양이온 전하(charge)를 가지며, 소수성(hydrophobic)과 친수성(hydrophilic) 아미노산에 의해 양친매성(amphipathic) 구조적 특성을 형성한다. 대부분의 항균활성 펩타이드는 미생물 막에 작용하여 세포막의 파괴를 유도하며, 또한 세포 내부로 투과 후 핵산과 작용하여 단백질 합성을 저 해 기능으로 함으로써 미생물 성장을 억제시킨다. 항균활 성 펩타이드는 $\alpha$-helical, $\beta$-sheet과 random-coil의 2 차 구조 (secondary structure)를 형성하며, 정확한 작용기전은 잘 알 려져 있지는 않지만 일반적으로 "Barrel-stave", "Toroidal pore", "Carpet" 모델 형성으로 박테리아 막 파괴를 유도하 며(Fig. 1), lipopolysaccharid (LPS)와 lipoteichoic acid (LTA) 에 강한 binding을 형성함으로써 박테리아 감염에 의한 내독소(endotoxin)를 억제하여 septic shock을 예방할 수 있 다(Fig. 2) (10). 현재까지 보고된 많은 항균활성을 갖는 펩 타이드들 가운데 가장 잘 알려진 Alamethicin, Magainin-2, Cathelicidin-/LL37, Melittin, Temporin 펩타이드의 작용기전 및 효과에 대해 기술하고자 한다(Table 1) (11). 
Table 1. Characterization, activity, and mechanism of antimicrobial peptides.

\begin{tabular}{|c|c|c|c|}
\hline Peptides & Characterization & Activity & Mechanism \\
\hline Alamethicin & $\begin{array}{l}\text { - Extraction of fungus } \\
\text { Trichoderma viride }\end{array}$ & $\begin{array}{l}\text { - Antimicrobial activity and } \\
\text { anti-fungal activity }\end{array}$ & $\begin{array}{l}\text { - Amphipathic } \alpha \text {-helical/cyclic structure } \\
\text { (Barrel-stave model) }\end{array}$ \\
\hline Magainin-2 & $\begin{array}{l}\text { - Identified in the Skin of the } \\
\text { African clawed frog Xenopus } \\
\text { laeyis }\end{array}$ & $\begin{array}{l}\text { - Antimicrobial activity } \\
\text { - Lower cytotoxicity }\end{array}$ & $\begin{array}{l}\text { - Electrostatic interaction to } \\
\text { microorganism } \\
\cdot \text { Hydrophobic and amphipathic } \\
\alpha \text {-helical structure (Toroidal pore) }\end{array}$ \\
\hline Cathelicidin-LL-37 & $\begin{array}{l}\text { - Found at human mucosal } \\
\text { surfaces } \\
\text { - Cationic, amphipathic host } \\
\text { defense peptide }\end{array}$ & $\begin{array}{l}\text { - Antimicrobial activity and lower } \\
\text { hemolysis and cytotoxicity } \\
\text { - Neutralizing activity (LPS, LTA) } \\
\text { - Inhibition of bacterial biofilms } \\
\text { - Anti-infective and } \\
\text { immunomodulatory activity }\end{array}$ & $\begin{array}{l}\text { - Presence of membranes: } \alpha \text {-helical } \\
\text { structure } \\
\text { - Membrane disruption and insertion } \\
\text { into the bacteria membrane } \\
\text { (Toroidal pore) }\end{array}$ \\
\hline Melittin & $\begin{array}{l}\cdot \text { Extraction of European } \\
\text { honey bee } \text { Apis mellifera } \\
\text { - Hydrophobic }\end{array}$ & $\begin{array}{l}\text { - Antimicrobial activity } \\
\text { - Hemolysis and cytotoxicity }\end{array}$ & $\begin{array}{l}\text { - Presence of membranes: } \alpha \text {-helix } \\
\text { structure } \\
\text { - Amphipathic structure } \\
\text { - Disrupts to cell membranes } \\
\text { (Carpet model) }\end{array}$ \\
\hline Temporins & $\begin{array}{l}\text { - Identified in the skins of the } \\
\text { European frogs } R \text {. esculenta } \\
\text { and } R \text {. temporaria }\end{array}$ & $\begin{array}{l}\text { - Active mainly against } \\
\text { Gram-positive bacteria, Candia } \\
\text { - Not toxic to hRBCs } \\
\text { - Cancer activity } \\
\text { - Endotoxin neutralization activity }\end{array}$ & $\begin{array}{l}\text { - Formation of transmembrane pores } \\
\text { rather than causing a detergent-like } \\
\text { disruption of the cell membrane } \\
\text { - Hydrophobic and } \alpha \text {-helical } \\
\text { - LPS neutralization activity }\end{array}$ \\
\hline
\end{tabular}

\section{1. 펩타이드 작용 메커니즘}

\section{1-1. Barrel stave model 메커니즘}

Barrel-stave model 항균활성 펩타이드는 펩타이드의 소 수성 부위가 세포막의 이중층(bilayers) 막의 lipid core 부 위에 작용하며, 펩타이드의 친수성 부위가 내부에 위치하 여 세포막 관통으로 구멍(transmembrane pore)을 형성 후 세포사멸을 유발한다 (12). 항균활성을 갖는 다양한 펩타 이드 중 Alamethicin 펩타이드는 박테리아 막에 작용 시 "barrel-stave model" 메커니즘을 형성하는 것으로 보고되었 다. Alamethicin 항균활성 펩타이드는 진균의 Trichoderma viride로부터 분리된 항균활성 펩타이드이다. 총 18 개의 잔기로 구성된 cyclic 펩타이드로 7- $\alpha$-aminoisobutyric acid 잔기와 2 개의 glutamine 잔기 그리고 1 개의 free carboxyl group로 구성되어 있다. Alamethicin 펩타이드는 1 번의 proline과 17번의 glutamic acid의 $\gamma$-carboxyl에 imino group을 형성하여 cyclic을 형성하지만 산성화로 유도될 때 서열의 부분부분이 잘려진다. 그리고 펩타이드의 6번 glutamine, 18 번 glutamic acid 아미노산에 의해 artificial phospholipid 에 강한 상호작용으로 pore를 형성한다. 더 나아가 optical rotator dispersion $(\mathrm{ORD})$ 와 circular dichroism $(\mathrm{CD})$ 로 구조적 변화를 확인한 결과 약 $40 \%$ 가량 $\alpha$-나선형( $\alpha$-helical) 구조 를 형성하는 것으로 보고가 되었다 (13). 펩타이드가 세포 막에 작용할 때 단일-채널(single-channel) 전도도에 의해 "Barrel-stave model" 메커니즘을 유도하는 것으로 이온 채 널 활동에 단일 Alamethicin 펩타이드의 뭉치(aggregate)는 정도에 따라 채널의 변화가 일어나고, 채널활성은 전압에 의존성을 나타낸다. 1996년 He et al.에 의하면 dilauroyl phosphatidylcholine (DLPC)의 내부 직경이 1.8 nm, 외부 직경이 $4.0 \mathrm{~nm}$ 의 pore를 형성하며, 8 개의 Alamethicin 펩 타이드는 세포막에 작용하여 "Barrel-stave model"을 형성 한다 (14). 1977년 Pandey et al. 의해 보고된 Alamethicin (Ac-Aib-Pro-Aib-Ala-Aib-Ala-Gln-Aib-Val-Aib-Gly-Leu-AibPro-Val-Aib-Aib-Glu-Gln-Phl) (final structure) (15) 펩타이드 는 20 개의 아미노산으로 $\alpha$-나선형으로 구성되어 있으며, 그람양성 박테리아와 진균에 강한 활성(MIC, $1.5 \sim 25 \mu \mathrm{M})$ 을 갖는다. 그리고 그람음성 박테리아 LPS에 작용하며, 높은 농도 $(25 \mu \mathrm{M})$ 에서 Sinorhizobium meliloti 균의 성장을 억제한다 (16). 펩타이드는 8 개의 $\alpha$-aminoisobutyric acid (Aib), 1 개의 L-phenylalaninol ( $\mathrm{Phl}$ ) 잔기, polar side chain 
(Gln, Glu, Gln, Phl)/non-polar side chain (Val, Aib, Ala, Leu)과 $\mathrm{C}$-말단 부위에 음이온 전극을 형성하는 glutamic acid 잔 기를 갖는다. Alamethicin은 $\alpha$-나선형 펩타이드로 소수성 과 친수성으로 구성된 양친매성 구조로 약 $2.9 \mathrm{~nm}$ 길이 를 형성하며, side chain에 glutamic acid 아미노산은 펩타 이드가 막 전위(transmembrane) 상태일 때 양자를 가하여 (protonated) charge에 의한 효과는 유발되지 않는다. 그렇 지만 소수성 아미노산에 의해 박테리아 막에 친화력이 증가해 cylindrical pore formation (Barrel stave)으로 세포막 을 파괴하여 항균활성을 갖는다 (17).

\section{1-2. Toroidal pore 메커니즘}

Magainins 펩타이드는 1987년 Zasloff에 의해 African clawed-frog Xenopuslaevis 피부의 granular gland에서 발견 이 되었다 (18). 총 23 개의 아미노산 잔기를 갖는 펩타이 드로 Magainin 1 (GIGKFLHSAGKFGKAFVGEIMKS)과 Magainin 2 (GIGKFLHSAKKFGKAFVGEIMNS)로 명명이 되었으며, bacteria, fungi, protozoa 등에 선택적으로 강한 항균활성(10 100 $\mu \mathrm{g} / \mathrm{ml})$ 을 갖는다 (19). 반면, 적혈구세포 (erythrocytes)와 같은 동물의 세포에서는 높은 농도인 1 $\mathrm{mg} / \mathrm{ml}$ 이상에서 세포독성을 갖는다 (20). Magainins 펩타 이드는 박테리아 막과 동물세포막에 각각 서로 다른 작 용 메커니즘에 의해 세포독성을 나타낸다 (21). 박테리아 막은 phosphatidylglycerol (PG)와 cardiolipin (CL)인 음이온 전극(negatively charge)으로 인지질(phospholipid)이 비대칭 적(asymmetric)으로 위치하고 있으며, 이들 음이온 지방산 은 박테리아 막에 대략 $50 \%$ 를 포함한다. 특히 그람 음 성균의 막은 다량의 음이온인 LPS로 둘러 싸여 있으며, septic shock에 약 $75 \%$ 이상을 유발한다 (22). 펩타이드는 음이온 막(anionic membranes)에 선택적인 작용을 하여 막 파괴에 영향을 미친다. 최초 막에 작용은 소수성 상호작 용(hydrophobic interactions)으로 세포막의 소수성 잔기와 펩타이드의 비극성(non-polar) 아미노산에 작용한다. 그리 고 세포막 lipids의 음이온 전극 부위와 펩타이드의 양이 온 전극(positive charge)에 정전기적 상호작용(electrostatic interaction)을 보인다 (23). Magainins 펩타이드는 중성인 $\mathrm{pH}$ 의 수용액에서는 거의 이차구조를 형성하지 않지만, 산성인 인지질 이중 층에서는 $\alpha$-나선형( $\alpha$-helical) 구조를 $60 \sim 90 \%$ 가량 형성하며, 약 $180^{\circ} \mathrm{C}$ 의 극성 각(polar angles) 에 의해 이상적인 양친매성 나선형을 형성한다 (24 28). Blazyk와 그의 동료는 Magainin 펩타이드가 박테리아의 외부 막인 peptidoglycan에 작용하여 막의 lipid 조직을 파
괴한다는 것을 확인하였다 (29 31). 특히, Magainin 2 펩 타이드는 대장균 막의 LPS에 작용하여 $\alpha$-나선형 형성을 유도하며 (32), lipid A에 부착 후 막 표면에 blebs 형성을 유도한다 (33). 또한 Guiotto et al.과 Matsuzaki et al.은 Magainin 2 펩타이드의 용해도(solubility)를 높이고자 N말단 부위에 $\mathrm{PEG}\left(\mathrm{M}_{\mathrm{W}}=5,000\right)$ 를 결합시킨 결과 $\mathrm{PEGs}$ 에 의해 펩타이드의 양이온과 박테리아 막의 음이온 결합 이 감소함으로써 세포막 투과가 줄어들어 낮은 항균활 성을 보이지만 용해도는 높아지는 것으로 보고되었다 $(34,35)$. 반면, PEGylated된 펩타이드의 세포막 작용 메커 니즘이 아직까지는 완전히 알려지지 않았으나, 2013년에 Han과 Lee에 의해 보고된 바에 의하면, 수용성 용액에서 Magainin 2 펩타이드의 양이온 잔기와 PEGs의 산소 원자 의 소수성 상호작용에 의해 펩타이드가 뭉치는 효과를 나타낸다. 그러므로 Magainin 2 펩타이드의 양이온과 세 포막 음이온의 낮은 정전기적 상호작용에 의해 항균활성 을 감소시킨다. 특히 랜덤 코일(random-coil)의 Magainin 2 펩타이드는 PEGs chain에 더 높은 작용으로 세포막 투 과(membrane-permeabilizing) 활성이 감소하는 것으로 보 고되었다 (36). 더 나아가 Magainin 2 펩타이드는 각종 암 세포(MDA-MB-231, T-47D, MCF-7; breast cancer line)에 강한 세포독성을 나타내는 것으로 지속적으로 보고가 되 고 있다 $(37,38)$. 특히 MDA-MB-231과 M14K 암세포에 Magainin 2 펩타이드를 다양한 방법으로 적용하여 세포 독성 작용기작을 분석한 결과 펩타이드 농도에 의존하 여 세포자멸사(apoptosis)를 유발하는 것으로 보고가 되었 다 (39). 그러므로 Magainin 2 펩타이드는 강한 항균활 성을 보이며, PEGylation을 통해 항균활성은 감소되지만 solubility가 증가되었으며, 각종 암세포(cancer cells)에 강 한 세포독성을 나타내므로 향후 다양한 분야에 적용이 가능할 것으로 여겨진다.

또한, Caths protein에 유래된 항균활성을 갖는 Cathelicidin 펩타이드는 $\mathrm{N}$-말단(N-terminal)의 신호전달 펩타이드 (signal peptide) group과 cathelin peptide group 그리고 C말단(C-terminal)의 Cathelicidin group으로 elastase 또는 proteinase 3 에 의해 Cathelin-like domain이 절단된 항균활 성을 갖는 펩타이드로 구성된다 $(40,41)$. Cathelicidin 펩 타이드는 proline/arginine (PR)을 1 2개 이상 포함한 39개 아미노산으로 구성된 물질로 항균활성과 피부상처 치유 에 효과를 나타낸다 (42). 또한 hCAP18/LL37로 불리는 Cathelicidin 항균활성 펩타이드는 피부의 염증 유발 시 
neutrophils, mast cells, keratinocytes (in neonatal skin)와 exocrine glands에서 즉각적으로 분비되며, 2개의 leucine으 로부터 시작하는 37 개의 아미노산으로 구성된 펩타이드 로 LL37이라 명명되었다 $(43,44)$. hCAP18/LL37 펩타이드 는 침샘(saliva)과 땀샘(sweat)에서 분비되어 serine proteases 에 의해 다양한 길이(31 aa, $30 \mathrm{aa}, 27 \mathrm{aa}, 19 \mathrm{aa})$ 의 펩타이 드로 잘리며, 특히 RK-31과 KS-30으로 알려진 두 개의 유사한 펩타이드는 피부염 유발에 잘 알려진 박테리아 (Staphylococcus aureus)에 항균활성의 증가를 보이는 것으 로 보고가 되었다 (45 48). hCAP18/LL37 항균활성 펩타 이드는 박테리아의 음이온 막에 작용하는 양이온 전극과 세포막 지방(lipid membrane)에 삽입되는 소수성 잔기로 분리된 양친매성 $\alpha$-나선형 구조로 각종 bacteria (gramnegative, gram-positive), fungi에 강한 항균활성을 갖는다. 세포막 파괴 유도 시 펩타이드는 박테리아 이중층 막 지 질의 머리 부분의 음이온(acyl chains in the hydrophobic core of the bilayer)과 강한 상호작용으로 Barrel-stave like pore model 형성하지만, 높은 농도를 처리하면 Toroidal-pore model 또는 세포막의 micelle 형성을 유도하여 파괴시키 는 메커니즘을 갖는다 $(49,50)$. 반면 각종 미생물의 감 염 시 인간의 백혈구 세포 주화성(chemoattractant)에 영향 을 받아 LL37 펩타이드 최상의 농도는 $10^{-5} \mathrm{M}$ 로 대부분 chemotactic 반응들에 "high-affinity ligand-receptor interaction" 에 기초하지만, LL-37과 formyl peptide receptor-like 1 (FPRL1)은 low-affinity ligand-receptor interaction을 나타낸 다 $(51,52)$. 보통 LL37 펩타이드 농도는 정상적인 사람 의 기도상피세포에서 $2 \mu \mathrm{g} / \mathrm{ml}\left(4 \times 10^{-7} \mathrm{M}\right)$ 이지만, 염증 반응 시에는 10 50배 이상 mRNA와 단백질이 발현한다. 특히 기도염증은 LL37 펩타이드 발현을 50 배 $\left(2 \times 10^{-5} \mathrm{M}\right)$ 증가시켜 감염된 미생물을 파괴시키는 것으로 보고가 되었다 $(53,54)$. 반면 동물세포막(hRBC, leukocytes, Tlymphocyte 등)에 소수성 상호작용에 의해 높은 농도에 서 세포독성을 보인다 (55 57). 또한 각종 박테리아에 감 염되면 pro-inflammatory cytokines (TNF- $\alpha$, Interleukin-6, interleukin-1ß), nitric oxide (NO) 등이 분비되어 septic shock 을 유발하지만 hCAP18/LL37 펩타이드가 염증부위에 분 비되며 박테리아 사멸 및 이들 막에 위치한 endotoxin 의 neutralization을 유도하여 감염에 의한 inflammation과 septic shock을 예방한다 (58 68).

1-3. Carpet model 메커니즘

"Carpet model" 펩타이드는 박테리아 막의 bilayer surface
에 작용하여 항균활성을 나타낸다. 펩타이드는 세포막의 음이온인 인지질(phospholipid head) 부위에 정전기적 상 호작용으로 세포막을 둘러싸며, 세포막 bilayer를 투과하 여 "Detergent-like" 방법으로 파괴시킨다 (12). 각종 생명 체에서 분리된 항균활성을 갖는 펩타이드 중 다양한 연 구를 통해 많이 보고가 된 Melittin 펩타이드는 박테리아 막에 작용/삽입되어 파괴시키는 것으로, 2012년 Naiyan $\mathrm{Lu}$ 등에 의해 "Carpet model" 메커니즘으로 보고가 되었 다 (69). Melittin 펩타이드는 1965년에 Habermann E에 의 해 유럽 꿀벌인 Apis mellifera의 독에서 분리한 펩타이드 로 26개(AIGAVLKVLTTGLPALISWIKRKRQQ)의 아미노 산으로 구성되어 있다 (70). Melittin 펩타이드는 낮은 농 도 $(1 \mu \mathrm{g} / \mathrm{ml})$ 에서 적혈구 세포에 빠르게 작용하여 강한 용 혈작용을 유도하는데 헤모글로빈(hemoglobin)을 세포 내 부로 분비시켜 독성을 유발한다 $(71,72)$. Melittin 펩타이 드는 박테리아 막과 작용 시 다양한 방법으로 상호작용 을 하는데 세포 막의 인지질 구성 성분, 펩타이드 농도, $\mathrm{pH}$, 막 전위(membrane potential) 그리고 막 인지질의 수화 (hydration) 등이 영향을 미친다 (73). 1990년 Christopher E. Dempsey에 의해 보고된 Melittin 펩타이드의 구조적 기능 과 특성은 합성된 펩타이드(인위적으로 $\mathrm{C}$-말단에 -NH2 위치시킴)의 아미노산 서열 중 소수성 잔기(hydrophobic residues)가 수용성 상태에서 세포막에 많은 영향을 미친 다. 또한 펩타이드 서열 중 양전하를 포함하고 있는 lysine과 arginine 아미노산은 6가의 양이온을 형성하며, C-말단 4개의 아미노산인 K-R-K-R과 N-말단 부위에 위 치하는 lysine이 세포막 작용에 중요한 역할을 하는 것으 로 알려졌다. Melittin 펩타이드는 수용성 상태에서 자연적 으로 양친매성 $\alpha$-나선형 2 차 구조를 형성하여 세포막 작 용에 강하게 영향을 미친다. 이러한 구조 형성은 수용성 상태에서 펩타이드 농도, $\mathrm{pH}$, 각종 이온 등에 의해 약간 의 뭉침 현상을 유도하고 (74), 비극성상태에서 소수성 잔기에 의해 self-association으로 사량체(tetramer) 구조를 형성하여 entropic 현상이 일어나며, 소수성이 증가하게 된다 (75). Melittin 펩타이드는 최소농도 억제에서는 단량 체(monomer)를 형성하여 세포막에 구멍(pore)을 형성하여 파괴시킨다 (76). 반면 높은 농도는 뭉침 현상의 사량체 구조를 형성하여 신경말단에 탈분극(depolarization)을 일 으켜 통증을 나타내는 것으로 보고되었다 (77). 최근까지 Melittin 펩타이드는 미생물 막 파괴에 미치는 mechanism 에 관해 많은 연구가 되어 왔다. 2013년 Ming-Tao Lee et al. 
에 의하면 Melittin 펩타이드가 세포막에 작용 시 transient pore을 형성하여 막 전위 전도(transmembrane conduction) 때 원자 이온(atomic ion)들을 배출시키지만 glucose 또는 거대 분자(larger molecule)들은 세포 외부로 배출을 시키 지 않으며, 펩타이드에 의한 안정적인 구멍에 의해 수십 개의 kilodaltons 분자를 세포 내부로 배출하므로 항균활 성을 갖는 것으로 보고되었다 (78). 또한 Melittin 펩타이 드는 항균작용뿐만 아니라 강한 항암작용을 나타내는 것 으로 보고되었다. 1985년 Hait et al.에 의하면 Melittin 펩 타이드는 인간의 백혈병세포에 Calmodulin 억제제로 세 포 증식 및 성장을 억제하며, 1986년에는 Killion과 Dunn 은 Melittin 펩타이드가 백혈병세포에서 정상적인 마우스 비장세포 및 골수세포보다 더 많은 민감도를 보이는 것은 이들 세포막에 carbohydrates(탄수화물) binding site에 작용 함으로써 나타나며 (79), 2007년 Son et al.에 의하면 종양 세포(tumor cell)에서 Melittin 펩타이드는 PLA2의 활성을 강화시키므로 세포독성을 유발하는 것으로 보고하였다 (80). Melittin 펩타이드는 다양한 암세포의 괴사(necrosis) 또는 세포자멸사를 유도시켜 세포독성을 유발하게 된다. 이러한 작용을 통해 Melittin 펩타이드는 각종 미생물 및 암세포에 작용하여 세포사멸을 유도하므로 인간의 적혈 구 세포에 대한 독성을 없애거나 줄이면 차후 사용 가치 가 높을 것으로 예상된다.

\section{Neutralization (LPS/LTA) 메커니즘}

\section{2-1. LPS binding 메커니즘}

그람음성균 막에 위치한 LPS는 O-antigen, core, lipid A (endotoxin)로 구성이 되어 있다. 각종 그람음성균의 감 염은 LPS에 강한 독성으로 septic shock을 유발하지만 각 종 항균활성 펩타이드는 LPS의 lipid A와 강한 정전기 적 상호작용으로 septic shock 유발을 억제하는 것으로 보 고되고 있다 (81). 다양한 항균활성을 갖는 펩타이드 중 Temporin은 1996년 European red frog Ranatemporaria의 피 부로부터 cDNA encoding에 의해 분리된 짧은 아미노산으 로 구성된 소수성을 갖는 항균성 펩타이드이다. Temporin 펩타이드는 2 개의 양이온 전극의 아미노산을 포함하고 있으며, 각종 박테리아에 항균활성(antibacterial activity)을 갖는다. 반면 펩타이드의 아미노산을 치환함으로써 항균 활성을 보이지 않거나 또는 세포독성이 감소하는 것으로 Temporin 펩타이드는 아미노산의 특성이나 위치에 따라 항균활성 및 세포독성에 영향을 미친다 (82). 또한 북미와
유라시아 개구리에서뿐만 아니라 말벌의 독(wasps venom) $(83,84)$ 그리고 양서류에서 이와 유사한 펩타이드가 발 견되었다 (85). Temporin 펩타이드는 아미노산 서열치환 및 C-말단(C-terminal)에 amidation (-NH2)으로 약 40개의 Temporin family를 구성하며, 다양한 생물학적 기능 및 활 동 메커니즘을 나타낸다. 이들 펩타이드들의 특징으로는 $10 \sim 14$ 개의 짧은 서열의 아미노산을 구성하는 양친매성 $\alpha$-나선형 항균활성 펩타이드이며, 중성 $\mathrm{pH}$ 에 비교적 낮은 순 양전하(net positive charge)를 갖는다. 그리고 각종 병원 균(pathogens)에 빠르고 신속하게 작용하여 활성을 보이 며, 정상적인 동물세포에 대한 세포독성은 아주 낮은 것 으로 보고되었다. 대부분의 Temporin은 주로 양이온 $\alpha$ 나선형 펩타이드로 미생물의 세포원형질 막(cytoplasmic membrane)에 작용하여 파괴시키는 메커니즘을 갖지만 소 수의 Temporin 펩타이드는 면역조절에 관여하는 것으로 보고되었다 $(86,87)$. 지속적인 연구결과 76 개의 Temporin 펩타이드를 유도하였고, 대부분의 펩타이드는 leucine, alanine 그리고 lysine 아미노산이 많이 위치하며, 중성인 $\mathrm{pH}$ 에서 lysine, histidine 그리고 arginine에 의해 0 에서 +4 가의 낮은 전극을 갖는다 (88). 이들 Temporin 펩타이드의 세포독성 메커니즘은 완전히 밝혀지진 않았지만, 다양한 메커니즘들 중 하나로 선천적 면역 반응(innate immunity) 작용은 양이온 펩타이드와 박테리아 외막(outer membrane, $\mathrm{OM})$ 의 인산그룹(phosphate groups)인 음이온(Gram-negative, LPS, Gram-positive, LTA)과 정전기적 상호작용에 의해 강한 중화작용(neutralization)을 유도한다 (89). 특히 그람 음성균 막의 LPS는 lipid A에 이당류 인산화 글루코사민 (disaccharide of phosphorylated glucosamines)이 위치하고 있으며, 6개 또는 7개의 포화지방산(saturated fatty acids) 의 부착과 친수성 O-항원 도메인(hydrophilic O-antigenic domain)에 당(saccharide)이 반복되어 막 구성을 한다 (90, 91). 다수 항균활성 펩타이드는 LPS에 정전기적 상호작용 후 지속적으로 소수성 상호작용에 의해 세포 내부 막에 영향을 미치는 것으로 Temporin L 펩타이드 또한 LPS에 작용과 함께 세포막을 파괴시키는 구조적 작용 기전을 갖 는다. 그렇지만 minimum inhibitory concentration보다 높은 농도에 의해 세포막 붕괴와 함께 내부로 삽입되어 세포 사멸을 유발시킨다 (92). 이러한 작용으로 Temporin 항균 활성 펩타이드가 박테리아 막에 강한 파괴능력 및 내독 소 물질인 LPS와 빠르게 작용해 중화작용을 유도하므로 세포 독소로부터 다양한 질병을 예방할 수 있을 것이다. 


\section{2-2. LTA binding 메커니즘}

대부분의 그람양성균의 외부 막은 techoic acids (TAs) 또는 glycopolymers로 구성되어 있으며, TAs는 wall teichoic acid (WTA)와 LTA로 분류된다. WTA는 세포막의 Peptideoglycan $(\mathrm{PG})$ 과 LTA는 세포원형질막에 결합하여 위치 한다 (93). TAs는 음이온 전극의 인산그룹과 양이온 전극 의 아미노산이 반복적으로 위치하여 쌍성이온(Zwitterionic)을 나타낸다. 일반적으로 잘 알려진 그람양성균인 S. aureus 의 TAs는 Ribitol phosphate (Rbo-P)와 Glycerol phosphate (Gro-P)로 구성되어 있다. 그리고 WTA는 Nacetylmannosamine (ManNAc)와 N-acetylglucosamine-1-P (GlcNac)의 disaccharide 구성물을 통한 N-acetylmuramic acid (MurNAc)의 6-OH에 공유결합(covalently linked) 하며, LTA 중합체는 glycolipid anchor에 의해 세포원형질 막에 부착된다. 또한 LTA backbone은 종종 Gro-P가 반복된 단 위로 형성된다 (94 96). 각종 그람양성균에 의한 감염은 다양한 질병 유발과 함께 LTA의 toxic 물질에 의해 septic shock을 일으킨다. 세포막에 위치한 LTA는 면역세포의 Toll-like receptor-2 (TLR-2)와 binding하여 각종 신호전달 단백질인 $\mathrm{MyD} 88$ 과 $\mathrm{Mal}$ 의 작용으로 $\mathrm{IL}-1$ receptor associated kinase, TNF receptor associated factor 6, TNF receptor associated kinase 그리고 IKB kinase를 활성화시키고 이와 함께 NF-kB의 활성화에 의해 inflammatory cytokines인 TNF- $\alpha$, interleukin- 6 그리고 interleukin- $1 \beta$ 등을 다량으로 분비하므로 septic shock을 유발하게 된다 (97 99). 반면 다양한 미생물이 감염되면 innate host defense mechanism 에 의해 백혈구와 상피세포(epithelial cell) 등에서 항균활 성을 갖는 Defensin과 Cathelicidine 등 각종 펩타이드가 분비되고 이들의 미생물 막 파괴활성에 의해 강한 항균 활성을 갖는 것으로 보고가 되었다 (100). 특히 박테리아 막 작용 메커니즘에 잘 알려진 Cathelicidin/LL37 항균활 성 펩타이드는 LPS뿐만 아니라 LTA의 pro-inflammatory activity를 강하게 neutralize시킨다. 그래서 S. aureus와 같은 그람양성균의 감염으로부터 항균활성 펩타이드인 Cathelicidin/LL37은 강한 LTA에 작용에 의한 neutralization 으로 septic shock 유발을 억제할 수 있는 것으로 보고되 고 있다 (101).

\section{CONCLUSION}

다양한 미생물의 감염으로부터 각종 항생제의 오·남
용은 빠른 저항성을 획득하여 심각한 질병을 생성하며, 심할 경우 사망에 이르게 된다. 그러므로 신체 대사 및 방어체계에 영향을 미치지 않는 항생제 대체물질 발견 및 개발을 통한 적용이 필요하다. 그것들 중 하나의 물질 인 항균활성 펩타이드는 지속적으로 활발히 연구가 되고 있다. 특히 미생물의 감염에서 심각한 질병을 유발하는 원인 중의 하나인 LPS와 LTA는 septic shock의 원인으로 심할 경우 사망에 이른다. 그렇지만 Alamethicin, Magainin2, Cathelicidin/LL37, Melittin, Temporin 펩타이드들은 박테 리아 막 작용에 따른 각종 파괴 메커니즘으로강한 항균 활성과 함께 LPS와 LTA에 강한 바인딩은 neutralization으 로 septic shock 억제 메커니즘을 갖는다. 그러므로 이들 항균활성 펩타이드는 박테리아 감염에 따른 각종 질병 예방에 적용 가능한 항생제 대체 후보물질이라 여겨진다.

\section{REFERENCES}

1) Zhang QG. Exposure to phages has little impact on the evolution of bacterial antibiotic resistance on drug concentration gradients. Evol Appl 2014;7:394-402.

2) Grummet JP, Weerakoon M, Huang S, Lawrentschuk N, Frydenberg M, Moon DA, et al. Sepsis and 'superbugs': should we favour the transperineal over the transrectal approach for prostate biopsy? BJU Int 2013.

3) Nordmann P, Naas T, Fortineau N, Poirel L. Superbugs in the coming new decade; multidrug resistance and prospects for treatment of Staphylococcus aureus, Enterococcus spp. and Pseudomonas aeruginosa in 2010. Curr Opin Microbiol 2007; 10:436-40.

4) Xu ZQ, Flavin MT, Flavin J. Combating multidrug-resistant Gram-negative bacterial infections. Expert Opin Investig Drugs 2014;23:163-82.

5) Ma L, Conover M, Lu H, Parsek MR, Bayles K, Wozniak DJ. Assembly and development of the Pseudomonas aeruginosa biofilm matrix. PLoS Pathog 2009;5:e1000354.

6) Adav SS, Lin JC, Yang Z, Whiteley CG, Lee DJ, Peng XF, et al. Stereological assessment of extracellular polymeric substances, exo-enzymes, and specific bacterial strains in bioaggregates using fluorescence experiments. Biotechnol Adv 2010;28:255-80.

7) Tsai MW, Lee DJ, Lai JY. Mass transfer limit of fluorescent dyes during multicolor staining of aerobic granules. Appl 
Microbiol Biotechnol 2008;78:907-13.

8) Roscia G, Falciani C, Bracci L, Pini A. The development of antimicrobial peptides as new antibacterial drugs. Curr Protein Pept Sci 2013;14:641-9.

9) Guilhelmelli F, Vilela N, Albuquerque P, Derengowski LD, Silva-Pereira I, Kyaw CM. Antibiotic development challenges: the various mechanisms of action of antimicrobial peptides and of bacterial resistance. Front Microbiol 2013;4:353.

10) Bahar AA, Ren D. Antimicrobial peptides. Pharmaceuticals (Basel) 2013;6:1543-75.

11) Lee JK, Ramamourthy Gopal, Park Y. The function and application of antimicrobial peptides. Appl Chem Eng 2011; 119-24.

12) Brogden KA. Antimicrobial peptides: pore formers or metabolic inhibitors in bacteria? Nat Rev Microbiol 2005;3: 238-50.

13) Payne JW, Jakes R, Hartley BS. The primary structure of alamethicin. Biochem J 1970;117:757-66.

14) Hall JE, Vodyanoy I, Balasubramanian TM, Marshall GR. Alamethicin. A rich model for channel behavior. Biophys $\mathrm{J}$ 1984;45:233-47.

15) Rinehart KL Jr, Cook JC Jr, Meng H, Olson KL, Pandey RC. Mass spectrometric determination of molecular formulas for membrane-modifying antibiotics. Nature 1977;269:832-3.

16) Amiche M, Seon AA, Wroblewski H, Nicolas P. Isolation of dermatoxin from frog skin, an antibacterial peptide encoded by a novel member of the dermaseptin genes family. Eur J Biochem 2000;267:4583-92.

17) Wang KF, Nagarajan R, Camesano TA. Antimicrobial peptide alamethicin insertion into lipid bilayer: A QCM-D exploration. Colloids Surf B Biointerfaces 2014;116:472-81.

18) Zasloff M. Magainins, a class of antimicrobial peptides from Xenopus skin: isolation, characterization of two active forms, and partial cDNA sequence of a precursor. Proc Natl Acad Sci U S A 1987;84:5449-53.

19) Matsuzaki K, Sugishita K, Harada M, Fujii N, Miyajima K. Interactions of an antimicrobial peptide, magainin 2, with outer and inner membranes of Gram-negative bacteria. Biochim Biophys Acta 1997;1327:119-30.

20) Matsuzaki K, Sugishita K, Fujii N, Miyajima K. Molecular basis for membrane selectivity of an antimicrobial peptide, magainin 2. Biochemistry 1995;34:3423-9.

21) Matsuzaki K, Nakayama M, Fukui M, Otaka A, Funakoshi S, Fujii N, et al. Role of disulfide linkages in tachyplesin-lipid interactions. Biochemistry 1993;32:11704-10.

22) Ramachandran G. Gram-positive and gram-negative bacterial toxins in sepsis: a brief review. Virulence 2014;5:213-8.

23) Matsuzaki K. Why and how are peptide-lipid interactions utilized for self-defense? Magainins and tachyplesins as archetypes. Biochim Biophys Acta 1999;1462:1-10.

24) Wieprecht T, Dathe M, Schümann M, Krause E, Beyermann M, Bienert M. Conformational and functional study of magainin 2 in model membrane environments using the new approach of systematic double-D-amino acid replacement. Biochemistry 1996;35:10844-53.

25) Matsuzaki K, Nakamura A, Murase O, Sugishita K, Fujii N, Miyajima K. Modulation of magainin 2-lipid bilayer interactions by peptide charge. Biochemistry 1997;36:2104-11.

26) Matsuzaki K, Sugishita K, Ishibe N, Ueha M, Nakata $S$, Miyajima $\mathrm{K}$, et al. Relationship of membrane curvature to the formation of pores by magainin 2. Biochemistry 1998; 37:11856-63.

27) Matsuzaki K, Mitani Y, Akada KY, Murase O, Yoneyama S, Zasloff $\mathrm{M}$, et al. Mechanism of synergism between antimicrobial peptides magainin 2 and PGLa. Biochemistry 1998; $37: 15144-53$

28) Matsuzaki K. Why and how are peptide-lipid interactions utilized for self-defense? Magainins and tachyplesins as archetypes. Biochim Biophys Acta 1999;1462:1-10.

29) Rana FR, Blazyk J. Interactions between the antimicrobial peptide, magainin 2, and Salmonella typhimurium lipopolysaccharides. FEBS Lett 1991;293:11-5.

30) Rana FR, Macias EA, Sultany CM, Modzrakowski MC, Blazyk J. Interactions between magainin 2 and Salmonella typhimurium outer membranes: effect of lipopolysaccharide structure. Biochemistry 1991;30:5858-66.

31) Miyata $T$, Tokunaga $F$, Yoneya $T$, Yoshikawa $K$, Iwanaga $S$, Niwa $\mathrm{M}$, et al. Antimicrobial peptides, isolated from horseshoe crab hemocytes, tachyplesin II, and polyphemusins I and II: chemical structures and biological activity. J Biochem 1989; 106:663-8

32) Matsuzaki K, Sugishita K, Harada M, Fujii N, Miyajima K. Interactions of an antimicrobial peptide, magainin 2, with outer and inner membranes of Gram-negative bacteria. Biochim Biophys Acta 1997;1327:119-30.

33) Imura Y, Nishida M, Ogawa Y, Takakura Y, Matsuzaki K. Action mechanism of tachyplesin I and effects of PEGylation. Biochim Biophys Acta 2007;1768:1160-9. 
34) Imura Y, Nishida M, Matsuzaki K. Action mechanism of PEGylated magainin 2 analogue peptide. Biochim Biophys Acta 2007; 1768:2578-85.

35) Han E, Lee H. Effects of PEGylation on the binding interaction of magainin 2 and tachyplesin I with lipid bilayer surface. Langmuir 2013;29:14214-21.

36) Cruciani RA, Barker JL, Zasloff M, Chen HC, Colamonici O. Antibiotic magainins exert cytolytic activity against transformed cell lines through channel formation. Proc Natl Acad Sci U S A 1991;88:3792-6.

37) Lacroix M, Leclercq G. Relevance of breast cancer cell lines as models for breast tumours: an update. Breast Cancer Res Treat 2004;83:249-89.

38) Anghel R, Jitaru D, Bădescu L, Bădescu M, Ciocoiu M. The cytotoxic effect of magainin II on the MDA-MB-231 and M14K tumour cell lines. Biomed Res Int 2013;2013:831709.

39) Zanetti M, Gennaro R, Romeo D. Cathelicidins: a novel protein family with a common proregion and a variable C-terminal antimicrobial domain. FEBS Lett 1995;374:1-5.

40) Zaiou M, Gallo RL. Cathelicidins, essential gene-encoded mammalian antibiotics. J Mol Med (Berl) 2002;80:549-61.

41) Gallo RL, Ono M, Povsic T, Page C, Eriksson E, Klagsbrun $\mathrm{M}$, et al. Syndecans, cell surface heparan sulfate proteoglycans, are induced by a proline-rich antimicrobial peptide from wounds. Proc Natl Acad Sci U S A 1994;91:11035-9.

42) Frohm M, Agerberth B, Ahangari G, Stâhle-Bäckdahl M, Lidén $\mathrm{S}$, Wigzell $\mathrm{H}$, et al. The expression of the gene coding for the antibacterial peptide LL-37 is induced in human keratinocytes during inflammatory disorders. J Biol Chem 1997;272:15258-63.

43) Murakami M, Ohtake T, Dorschner RA, Schittek B, Garbe C, Gallo RL. Cathelicidin anti-microbial peptide expression in sweat, an innate defense system for the skin. J Invest Dermatol 2002;119:1090-5.

44) Sørensen OE, Follin P, Johnsen AH, Calafat J, Tjabringa GS, Hiemstra PS, et al. Human cathelicidin, hCAP-18, is processed to the antimicrobial peptide LL-37 by extracellular cleavage with proteinase 3. Blood 2001;97:3951-9.

45) Zaiou M, Nizet V, Gallo RL. Antimicrobial and protease inhibitory functions of the human cathelicidin (hCAP18/ LL-37) prosequence. J Invest Dermatol 2003;120:810-6.

46) Murakami M, Ohtake T, Dorschner RA, Gallo RL. Cathelicidin antimicrobial peptides are expressed in salivary glands and saliva. J Dent Res 2002;81:845-50.
47) Murakami M, Lopez-Garcia B, Braff M, Dorschner RA, Gallo RL. Postsecretory processing generates multiple cathelicidins for enhanced topical antimicrobial defense. J Immunol 2004;172:3070-7.

48) Henzler Wildman KA, Lee DK, Ramamoorthy A. Mechanism of lipid bilayer disruption by the human antimicrobial peptide, LL-37. Biochemistry 2003;42:6545-58.

49) Thennarasu S, Tan A, Penumatchu R, Shelburne CE, Heyl DL, Ramamoorthy A. Antimicrobial and membrane disrupting activities of a peptide derived from the human cathelicidin antimicrobial peptide LL37. Biophys J 2010;98:248-57.

50) Murphy PM. The molecular biology of leukocyte chemoattractant receptors. Annu Rev Immunol 1994;12:593-633.

51) Zlotnik A, Morales J, Hedrick JA. Recent advances in chemokines and chemokine receptors. Crit Rev Immunol 1999;19:1-47.

52) Bals R, Weiner DJ, Meegalla RL, Wilson JM. Transfer of a cathelicidin peptide antibiotic gene restores bacterial killing in a cystic fibrosis xenograft model. J Clin Invest 1999;103: 1113-7.

53) Frohm Nilsson M, Sandstedt B, Sørensen O, Weber G, Borregaard N, Ståhle-Bäckdahl M. The human cationic antimicrobial protein (hCAP18), a peptide antibiotic, is widely expressed in human squamous epithelia and colocalizes with interleukin-6. Infect Immun 1999;67:2561-6.

54) Johansson J, Gudmundsson GH, Rottenberg ME, Berndt KD, Agerberth B. Conformation-dependent antibacterial activity of the naturally occurring human peptide LL-37. J Biol Chem 1998;273:3718-24.

55) Oren Z, Lerman JC, Gudmundsson GH, Agerberth B, Shai Y. Structure and organization of the human antimicrobial peptide LL-37 in phospholipid membranes: relevance to the molecular basis for its non-cell-selective activity. Biochem J 1999;341: 501-13.

56) Travis SM, Anderson NN, Forsyth WR, Espiritu C, Conway $\mathrm{BD}$, Greenberg EP, et al. Bactericidal activity of mammalian cathelicidin-derived peptides. Infect Immun 2000;68:2748 -55 .

57) Raetz CR, Whitfield C. Lipopolysaccharide endotoxins. Annu Rev Biochem 2002;71:635-700.

58) Schumann RR, Leong SR, Flaggs GW, Gray PW, Wright SD, Mathison JC, et al. Structure and function of lipopolysaccharide binding protein. Science 1990;249:1429-31.

59) Tobias PS, Ulevitch RJ. Lipopolysaccharide binding protein 
and CD14 in LPS dependent macrophage activation. Immunobiology 1993;187:227-32.

60) Wright SD, Ramos RA, Tobias PS, Ulevitch RJ, Mathison JC. CD14, a receptor for complexes of lipopolysaccharide (LPS) and LPS binding protein. Science 1990;249:1431-3.

61) Hailman E, Lichenstein HS, Wurfel MM, Miller DS, Johnson DA, Kelley M, et al. Lipopolysaccharide (LPS)-binding protein accelerates the binding of LPS to CD14. J Exp Med 1994;179:269-77.

62) Jiang Q, Akashi S, Miyake K, Petty HR. Lipopolysaccharide induces physical proximity between $\mathrm{CD} 14$ and toll-like receptor 4 (TLR4) prior to nuclear translocation of NF-kappa B. J Immunol 2000;165:3541-4.

63) Lee HK, Dunzendorfer S, Tobias PS. Cytoplasmic domainmediated dimerizations of toll-like receptor 4 observed by beta-lactamase enzyme fragment complementation. J Biol Chem 2004;279:10564-74.

64) Cohen J. The immunopathogenesis of sepsis. Nature 2002; 420:885-91.

65) Hardaway RM. A review of septic shock. Am Surg 2000;66: 22-9.

66) Kirikae T, Hirata M, Yamasu H, Kirikae F, Tamura H, Kayama F, et al. Protective effects of a human 18-kilodalton cationic antimicrobial protein (CAP18)-derived peptide against murine endotoxemia. Infect Immun 1998;66:1861-8.

67) Nagaoka I, Hirota S, Niyonsaba F, Hirata M, Adachi Y, Tamura $\mathrm{H}$, et al. Cathelicidin family of antibacterial peptides CAP18 and CAP11 inhibit the expression of TNF-alpha by blocking the binding of LPS to CD14(+) cells. J Immunol 2001;167:3329-38.

68) Sawa T, Kurahashi K, Ohara M, Gropper MA, Doshi V, Larrick JW, et al. Evaluation of antimicrobial and lipopolysaccharide-neutralizing effects of synthetic CAP18 fragment against Pseudomonas aeruginosa in a mouse model. Antimcrob Agents Chemother 1998;42:3269-75.

69) Lu N, Yang K, Yuan B, Ma Y. Molecular response and cooperative behavior during the interactions of melittin with a membrane: dissipative quartz crystal microbalance experiments and simulations. J Phys Chem B. 2012;116:9432-8.

70) Habermann E, Reiz KG. On the biochemistry of bee venom peptides, melittin and apamin. Biochem Z 1965;343:192-203.

71) Gevod VS, Birdi KS. Melittin and the 8-26 fragment. Differences in ionophoric properties as measured by monolayer method. Biophys J 1984; 45:1079-83.
72) Sessa G, Freer JH, Colacicco G, Weissmann G. Interaction of alytic polypeptide, melittin, with lipid membrane systems. J Biol Chem 1969;244:3575-82.

73) Dathe M, Wieprecht T. Structural features of helical antimicrobial peptides: their potential to modulate activity on model membranes and biological cells. Biochim Biophys Acta 1999;1462:71-87.

74) Lauterwein J, Brown LR, W?thrich K. High-resolution 1HNMR studies of monomeric melittin in aqueous solution. Biochim Biophys Acta 1980;622:219-30.

75) Drake AF, Hider RC. The structure of melittin in lipid bilayer membranes. Biochim Biophys Acta 1979;555:371-3.

76) Ladokhin AS, White SH. Folding of amphipathic alphahelices on membranes: energetics of helix formation by melittin. J Mol Biol 1999;285:1363-9.

77) Bechinger B. Structure and functions of channel-forming peptides: magainins, cecropins, melittin and alamethicin. J Membr Biol 1997;156:197-211.

78) Bechinger B, Lohner K. Detergent-like actions of linear amphipathic cationic antimicrobial peptides. Biochim Biophys Acta 2006;1758:1529-39.

79) Killion JJ, Dunn JD. Differential cytolysis of murine spleen, bone-marrow and leukemia cells by melittin reveals differences in membrane topography. Biochem Biophys Res Commun 1986;139:222-7.

80) Son DJ, Lee JW, Lee YH, Song HS, Lee CK, Hong JT. Therapeutic application of anti-arthritis, pain-releasing, and anti-cancer effects of bee venom and its constituent compounds. Pharmacol Ther 2007;115:246-70.

81) Jerala R, Porro M. Endotoxin neutralizing peptides. Curr Top Med Chem 2004;4:1173-84.

82) Simmaco M, Mignogna G, Canofeni S, Miele R, Mangoni ML, Barra D. Temporins, antimicrobial peptides from the European red frog Rana temporaria. Eur J Biochem 1996; 242:788-92.

83) Krishnakumari V, Nagaraj R. Antimicrobial and hemolytic activities of crabrolin, a 13-residue peptide from the venom of the European hornet, Vespa crabro, and its analogs. J Pept Res 1997;50:88-93.

84) Argiolas A, Pisano JJ. Isolation and characterization of two new peptides, mastoparan $\mathrm{C}$ and crabrolin, from the venom of the European hornet, Vespa crabro. J Biol Chem 1984; 259:10106-11.

85) Kuchler K, Kreil G, Sures I. The genes for the frog skin 
peptides GLa, xenopsin, levitide and caerulein contain a homologous export exon encoding a signal sequence and part of an amphiphilic peptide. Eur J Biochem 1989;179:281-5.

86) Skerlavaj B, Benincasa M, Risso A, Zanetti M, Gennaro R. SMAP-29: a potent antibacterial and antifungal peptide from sheep leukocytes. FEBS Lett 1999;463:58-62.

87) Oren Z, Lerman JC, Gudmundsson GH, Agerberth B, Shai Y. Structure and organization of the human antimicrobial peptide LL-37 in phospholipid membranes: relevance to the molecular basis for its non-cell-selective activity. Biochem J 1999;341: 501-13.

88) Chen Q, Wade D, Kurosaka K, Wang ZY, Oppenheim JJ, Yang D. Temporin A and related frog antimicrobial peptides use formyl peptide receptor-like 1 as a receptor to chemoattract phagocytes. J Immunol 2004;173:2652-9.

89) Rosenfeld Y, Shai Y. Lipopolysaccharide (Endotoxin)-host defense antibacterial peptides interactions: role in bacterial resistance and prevention of sepsis. Biochim Biophys Acta 2006;1758:1513-22.

90) Trent MS. Biosynthesis, transport, and modification of lipid A. Biochem Cell Biol 2004;82:71-86.

91) Rietschel ET, Kirikae T, Schade FU, Mamat U, Schmidt G, Loppnow $\mathrm{H}$, et al. Bacterial endotoxin: molecular relationships of structure to activity and function. FASEB J 1994; 8:217-25.

92) Mangoni ML, Papo N, Barra D, Simmaco M, Bozzi A, Di Giulio A, et al. Effects of the antimicrobial peptide temporin L on cell morphology, membrane permeability and viability of Escherichia coli. Biochem J 2004;380:859-65.

93) Weidenmaier C, Kokai-Kun JF, Kulauzovic E, Kohler T, Thumm G, Stoll H, et al. Differential roles of sortaseanchored surface proteins and wall teichoic acid in Staphylo- coccus aureus nasal colonization. Int J Med Microbiol 2008; 298:505-13.

94) Neuhaus FC, Baddiley J. A continuum of anionic charge: structures and functions of D-alanyl-teichoic acids in grampositive bacteria. Microbiol Mol Biol Rev 2003;67:686-723.

95) Fischer W. Physiology of lipoteichoic acids in bacteria. Adv Microb Physiol 1988;29:233-302.

96) Xia G, Kohler T, Peschel A. The wall teichoic acid and lipoteichoic acid polymers of Staphylococcus aureus. Int J Med Microbiol 2010;300:148-54.

97) Su SC, Hua KF, Lee H, Chao LK, Tan SK, Lee H, et al. LTA and LPS mediated activation of protein kinases in the regulation of inflammatory cytokines expression in macrophages. Clin Chim Acta 2006;374:106-15.

98) Liljeroos M, Vuolteenaho R, Morath S, Hartung T, Hallman $\mathrm{M}$, Ojaniemi M. Bruton's tyrosine kinase together with PI 3-kinase are part of Toll-like receptor 2 multiprotein complex and mediate LTA induced Toll-like receptor 2 responses in macrophages. Cell Signal 2007;19:625-33.

99) Lee IT, Wang SW, Lee CW, Chang CC, Lin CC, Luo SF, et $a l$. Lipoteichoic acid induces HO-1 expression via the TLR2/ MyD88/c-Src/NADPH oxidase pathway and Nrf2 in human tracheal smooth muscle cells. J Immunol 2008;181:5098-110.

100) Nell MJ, Tjabringa GS, Vonk MJ, Hiemstra PS, Grote JJ. Bacterial products increase expression of the human cathelicidin hCAP-18/LL-37 in cultured human sinus epithelial cells. FEMS Immunol Med Microbiol 2004;42:225-31.

101) Agerberth B, Charo J, Werr J, Olsson B, Idali F, Lindbom L, et al. The human antimicrobial and chemotactic peptides LL37 and alpha-defensins are expressed by specific lymphocyte and monocyte populations. Blood 2000;96:3086-93. 